\section{ECONOMICS}

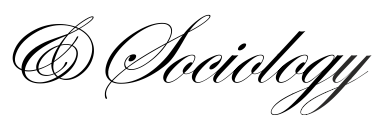

Nugraha, A. T., Prayitno, G., Situmorang, M. E., \& Nasution, A. (2020). The role of infrastructure in economic growth and income inequality in Indonesia. Economics and Sociology, 13(1), 102-115. doi:10.14254/2071-789X.2020/13-1/7

\title{
THE ROLE OF INFRASTRUCTURE IN ECONOMIC GROWTH AND INCOME INEQUALITY IN INDONESIA
}

\begin{abstract}
Achmad Tjachja Nugraha
Syarif Hidayatullab State Islamic

University, Jakarta, Indonesia

Email:achmad_ti@yaboo.com

ORCID 0000-0001-9184-7773

Gunawan Prayitno

Universitas Brawijaya, Malang,

Indonesia

Email:gunawan_p@ub.ac.id

ORCID 0000-0003-4534-9524
\end{abstract}

Masito Erlando Situmorang

BPS Puncak Jaya Regency,

Papua Province, Indonesia

Email:

masitositumorang@gmail.com

ORCID 0000-0001-8122-6850

\author{
Ahmadriswan Nasution \\ The Center of Education and \\ Training of BPS-Statistics \\ Indonesia \\ Email: \\ ahmadriswan73@gmail.com \\ ORCID 0000-0002-8028-7683
}

Received: May, 2019

1st Revision: October, 2019

Accepted: January, 2020

DOI: $10.14254 / 2071-$

789X.2020/13-1/7

JEL Classification: D63, $\mathrm{H} 54, \mathrm{O} 18, \mathrm{O} 47$
ABSTRACT. The relationship between infrastructure development, economic growth, and income inequality has always been debated. Those debates raised the question of "is there a role for infrastructure development in economic growth which in turn encourages a decline in income inequality?". This study aims to analyze the direct effect of infrastructure development on economic growth and the indirect effect - on income inequality. The present study used the Gini Ratio, Gross Regional Domestic Product (GRDP) data at constant market prices, investment, number of workforces, percentage of poor population, distribution of clean water, electricity distribution, and road length as of 2010-2016. The analytical methods applied here include descriptive method along with a twostep regression analysis method. The results reveal that infrastructure had a positive effect on economic growth, whereas direct economic growth harmed income inequality. These findings demonstrate that infrastructure indirectly reduces income inequality. Thus, infrastructure development, especially basic infrastructure and transportation, could reduce income inequality in Indonesia. Based on these findings, the government and related parties should encourage investment in basic infrastructure and transportation to improve economic performance sustainably.
Keywords: infrastructure, income inequality, economic growth, Indonesia 


\section{Introduction}

Development is a continuous process with the ultimate goal of improving people's welfare. Therefore, any development strategy must emphasize on the developments in both production and infrastructure to spur economic growth (Owolabi-Merus 2015, Chingoiro dan Mbulawa 2016, Kodongo \& Ojah 2016, Mbulawa 2017). Based on the objectives and development strategies, the implementation of development must be directed to the fields able to improve people's welfare.

The success of any development program is influenced by several factors, including macroindicators specified by economic growth. Therefore, high economic growth plays an important role in determining the success of economic development, both nationally and regionally. According to Arsyad (1997) and Tambunan (2001), economic growth is a major target that must be achieved in the process of economic development to increase national income. High economic growth is the primary target of development. However, the actors that contribute to economic growth should also be analyzed (Todaro, 2012). Rapid economic growth does not necessarily result in inequitable development. If only a few contribute to the economy, it will lead to income inequality.

Infrastructure is a determinant of economic development in addition to other general production factors such as capital and labor. Infrastructure development is believed to the ability to move the real sector, absorb labor, increase the consumption of the people and government, and encourage productive activities. This was confirmed by Hirschman (1958) who stated that infrastructure development is part of social overhead capital, which is important and needed to drive other economic sectors. Berndt and Hansson (1991) showed that an increase in public infrastructure capital could reduce production costs of the private sector. Morrison and Schwartz (1992) found that availability of infrastructure services proved to be able to reduce the production factor (costs). Calderdn and Serven (2004) revealed that infrastructure development could be very effective in dealing with poverty. Byoungki (2006) demonstrated that infrastructure investment could directly reduce production costs until productivity increases, increasing production in various regions. Finally, studies by Fay (2001) and Fay and Yepes (2003) showed that infrastructure investment had a positive effect on the economy.

Gross Domestic Product (GDP) is a measure of country's economic performance (Mankiw, 2007). GDP is useful in determining the direction of future development. Positive economic growth shows an increase in the economy, whereas negative economic growth reveals a decline. Based on BPS data, Indonesian GDP was 6,829.21 trillion rupiahs in 2010, which increased to $9,498.57$ trillions by 2016 . This number showed an increase of $28 \%$, meaning Indonesia's economic activity is quite good.

Meanwhile, the Gini ratio of Indonesian provinces has increased from 0.365 in 2010 to 0.394 in 2016. This number does not indicate a significant change and even though it tends to increase, the efforts addressing inequality have not been very impressive. Construction of physical infrastructures such as highways, railroads, telephone lines, and electricity can create additional productivity and improve income distribution (Chong \& Calderon, 2001).

Hidayat (2014) concluded that capital through investment is a production factor significantly and negatively affecting inequality. The availability of labor is another factor influencing inequality (Yeniwati, 2012). In addition to the capital factor and the availability of labor, the number of poor people also affects the inequality in income distribution. Idris (2005) concluded that the number of poor people had a positive and significant effect on the inequality of income distribution. Also, economic growth has a two-way relationship with income inequality. According to Tambunan (2003), growth and inequality have a strong 
correlation. Inequality tends to increase at the early stages of development, and it gradually decreases when approaching the final stages of development.

Thus, it is essential to analyze the factors directly or indirectly influencing the inequality of income distribution. It is also necessary to determine the factors playing roles in economic growth, as they indirectly affect the inequality of provincial income distribution in Indonesia. Generally speaking, this research intends to analyze the availability of public infrastructure and its effect on both economic growth and income distribution. It study aims to determine the magnitude of the influence of the availability of public infrastructure on economic growth and income distribution.

\section{Literature review}

The World Bank (1994) stated that there is no clear definition of infrastructure, but there is still a broad consensus on the meaning of infrastructure. According to the Macmillan Dictionary of Modern Economics (1996), infrastructure is a structural element of the economy that facilitates the flow of goods between buyers and sellers. Considering that, and according to the Routledge Dictionary of Economics (1995), infrastructure is the main service of a country allowing the realization of economic and social activities through the provision of means of transportation, public health services, educational services and buildings for community activities.

Infrastructure plays an important role in the performance of a country's economic growth. Its differentiation is also often based on its investments. Infrastructure discussions tend to lead to discussions on public goods. By understanding the nature of infrastructure as a public good, the theory of infrastructure is then akin to externality. This condition is consistent with the nature of the infrastructure provided by the government, and as parties using the infrastructure, do not pay directly.

Canning and Pedroni (2004) argued that infrastructure has the nature of externalities. Various infrastructures such as roads, educational facilities, and health services have positive externalities. It ensures that facilities provided by various infrastructures are positive externalities that can increase the productivity of all inputs in the production process. Positive externalities in infrastructure take the form of a contagion effect to increase the output of businesses and the agricultural sector without increasing capital and labor or technology levels. Through the construction of infrastructure, the level of productivity of enterprises and the agricultural sector will increase. One of the most visible infrastructure is the construction of roads (Hapsari, 2011).

Research examining the influence of infrastructure on economic development are also found in Indonesia. Yanuar (2006), using a panel of data from 26 provinces, showed that physical capital, infrastructure, telephone, health, and education had positive influences on economic growth. Other studies concluded that electricity, length of roads, capital stock and regional authority had positive effects on the economic development of the western Indonesian region. Meanwhile, the variable of clean water was not significant (Prasetyo (2008). Sibrani (2002) found that electricity and education positively and significantly contribute to the per capita income of the Indonesians, whereas the variables related to the road are not significant. Infrastructure development policies focused on Java and western Indonesia, resulting in income disparity. Prasetyo and Firdaus (2009) also focused on Indonesia's economic growth related to infrastructures, the completion of electrification, the construction of paved roads and the provision of clean water.

S. Kuznet in Jhingan (2013) defines economic growth as a long-term increase in a country's ability to provide more and more types of economic goods to its population. This capacity develops in the light of technological progress and the necessary institutional and 
ideological adjustments. Prof. Bauer shows that the key determinants of economic growth are talent, quality, skills, attitudes, customs, values, goals and motivations, as well as political and institutional structures (Jhingan, 2013), that can create prosperity.

Sukirno (2002) argued that prosperity is also determined by the availability of electricity, drinking water, school infrastructure and educational attainment, the level of available medical and health infrastructures, housing conditions infrastructure development, that are carried out.

Road construction is becoming a mean of connecting production areas and markets. It can also be said to bring production areas and markets together, or producers and consumers together. The role of transport (roads) is very important, especially as a mean of connection, reconciliation, and rapprochement between parties in need of each other (Adisasmita, 2011).

Based on the above image, it can be seen that the natural environment is fundamental support for all existing systems. The role of infrastructure as a mediator between the economic and social systems in human life with the natural environment becomes very important. A missing (or non-existent) infrastructure will have a major negative impact on human life. Conversely, too much infrastructure for the benefit of man without taking into account the carrying capacity of the environment will cause damages to nature, which, by nature, will harm humans, including other living beings. Given the importance of the infrastructure function as a supporter of social systems and economic systems, it needs to be clearly understood, especially by policymakers.

Apart from that, the link between infrastructure and economic growth is still under discussion, and at least two opinions were expressed on the influence of infrastructure on economic growth based on the results of research. The first opinion suggests that the influence of infrastructure on economic growth is positive (Aschauer, 1989). Meanwhile, the second opinion supports that the effect of infrastructure on economic growth is not even very negative (Holtz-Eakin, 1994).

\section{Research method}

The data used in this study were the Gini Ratio, Gross Regional Domestic Product (GRDP) at Constant Market Prices, investment, number of workforces, percentage of poor population, distribution of clean water, electricity distribution, and road length in 2010-2016. They were sourced from the Central Bureau of Statistics (BPS).

Descriptive and inferential analyses were used in this study. Descriptive analysis aims to observe the images of each variable in the model graphically. The inferencing analysis in this study was a regression with the Two-Stage Least Square (2SLS) method (Baltagi, 2005) in simultaneous recursive equations conducted in 33 Indonesian provinces using data in 20102016. Simultaneous regression of the recursive model was carried out to observe the relationship between economic growth, inequality and other variables of economic growth in Indonesia. Two structural equations will be formed, namely the equation of economic growth and the equation of inequality. The first equation, namely the equation of income inequality is as follows:

$$
\operatorname{Gini}_{i t}=\alpha_{0}+\alpha_{1} \ln \widehat{G R D} P_{i t}+\alpha_{2} \operatorname{lnFDI_{it}}+\alpha_{3} \operatorname{lnWorkforce_{it}}+\alpha_{4} \operatorname{lnPoor}{ }_{i t}+e 1_{i t}
$$

The second equation, namely the equation of economic growth is as follows:

$$
\operatorname{lnGRDP}_{i t}=\beta_{0}+\beta_{1} \operatorname{lnWater}_{i t}+\beta_{2} \text { lnElectricity }_{i t}+\beta_{3} \operatorname{lnRoad}_{i t}+e 2_{i t}
$$




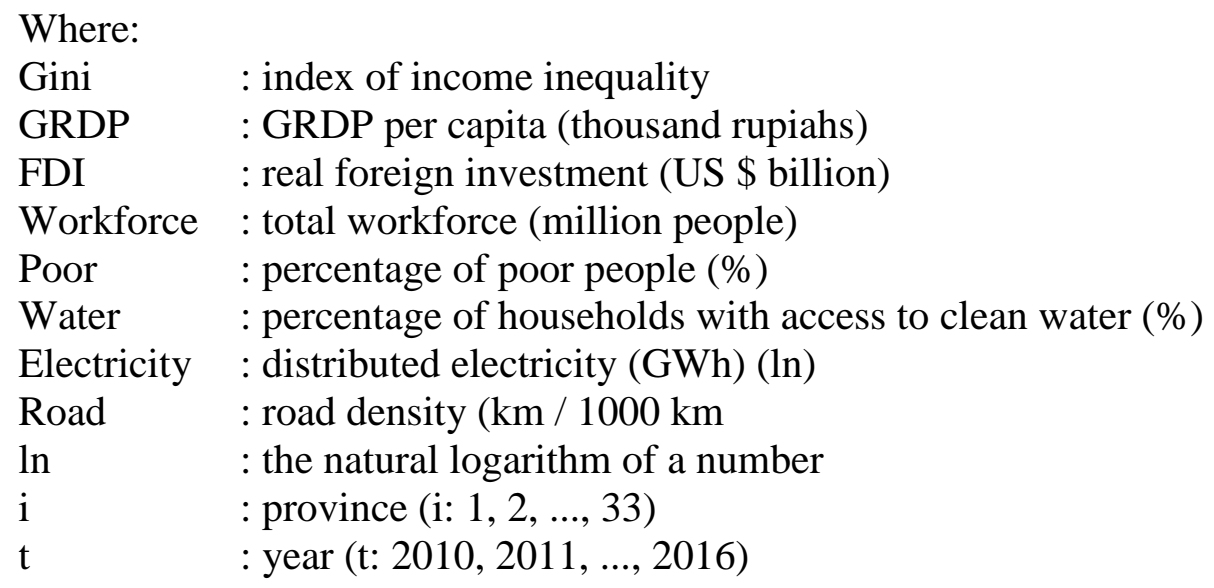

The identification of equations is carried out through the order and rank conditions. An equation can be identified if the order condition is $\mathrm{K}-\mathrm{k} \geq \mathrm{m}-1$. Meanwhile, the rank conditions can be fulfilled when the matrix in an equation with the order (M - 1) (M - 1) order, having a determinant that is not equal to zero and full rank. The simultaneity test was conducted to determine whether or not the variables identified as endogenous variables were true. Also, the appropriate estimation method for this simultaneous recursive analysis can be determined by conducting a multilevel test on a system of simultaneous recursive equations. If there is a simultaneity problem, the exact estimation method was ILS or 2SLS or 3SLS. Whereas, if there are no simultaneity problems, the OLS estimation method can be applied and will produce a consistent estimator. The Hausman Specification Error Test can be done to test this simultaneous problem. According to Gujarati (2015), this test is conducted by evaluating the residuals of the reduced form equation tested by looking at the level of significance of the reduced form error in the regression (in the structural equation).

Next is the effect test, which is done using the Chow Test, Lagrange Multiplier Test, and the Hausman Test. Testing is done to identify which effect is the most suitable for the model to be tested, whether CEM, FEM or REM. The 2SLS estimation is performed by regressing economic growth and inequality equations. It starts with a regression equation of structural economic growth with the OLS method to obtain the fit value of the $\ln$ GDRP variable, referring to the equation (2). The next stage is to regress the equation of structural inequality using the fit variable of economic growth, forming equation (1).

The classic assumptions tested included normality, homoscedasticity, nonmulticollinearity, and non-autocorrelation. A heteroscedasticity test with the Glejser test and autocorrelation test with the Durbin-Watson d test was done to test the FE2SLS model assumption. If there is autocorrelation in the model, then it is overcome with the HAC (Heteroscedasticity and Autocorrelation) Consistent Variance Newey West Section (Gujarati, 2006).

\section{Results and discussion}

\section{An overview of development indicators in Indonesia}

\section{Income inequality in Indonesia}

Income inequality can be illustrated with the Gini Ratio (Graph 1) to observe the spread of economic growth and determine whether or not there has been an equal distribution of income or income inequality. 


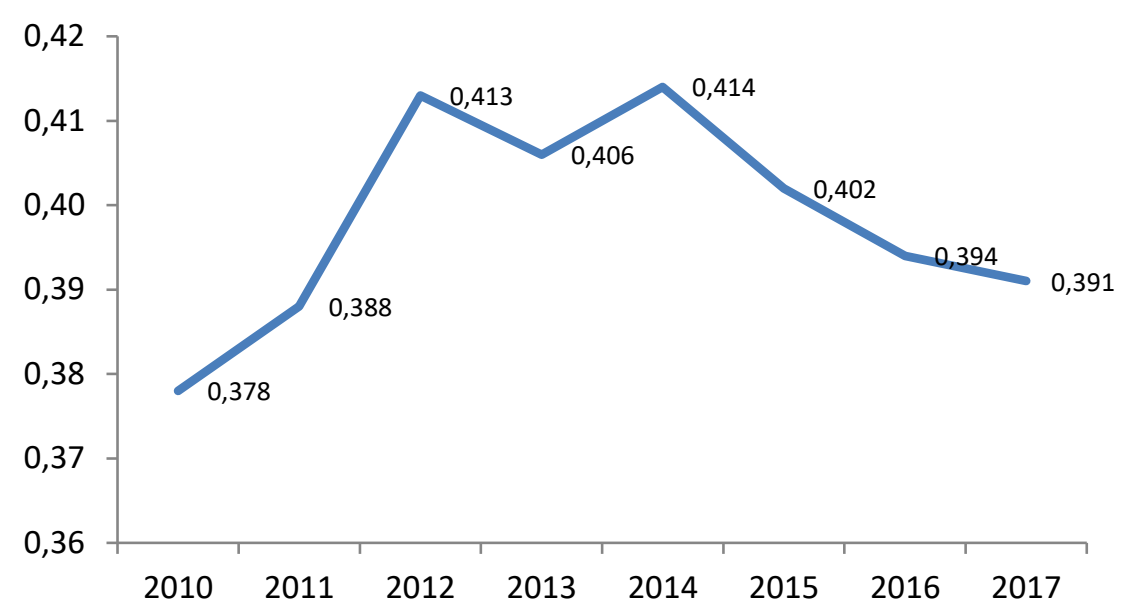

Graph 1. The Gini Ratio in Indonesia, years 2010-2016 Source: BPS-Statistics Indonesia

The average income inequality within the Indonesian population relatively increased from 2010 (by 0.378) to 2017 (by 0.391). This number increased by 0.021 points, signifying that the distribution of income in the community is increasingly uneven.

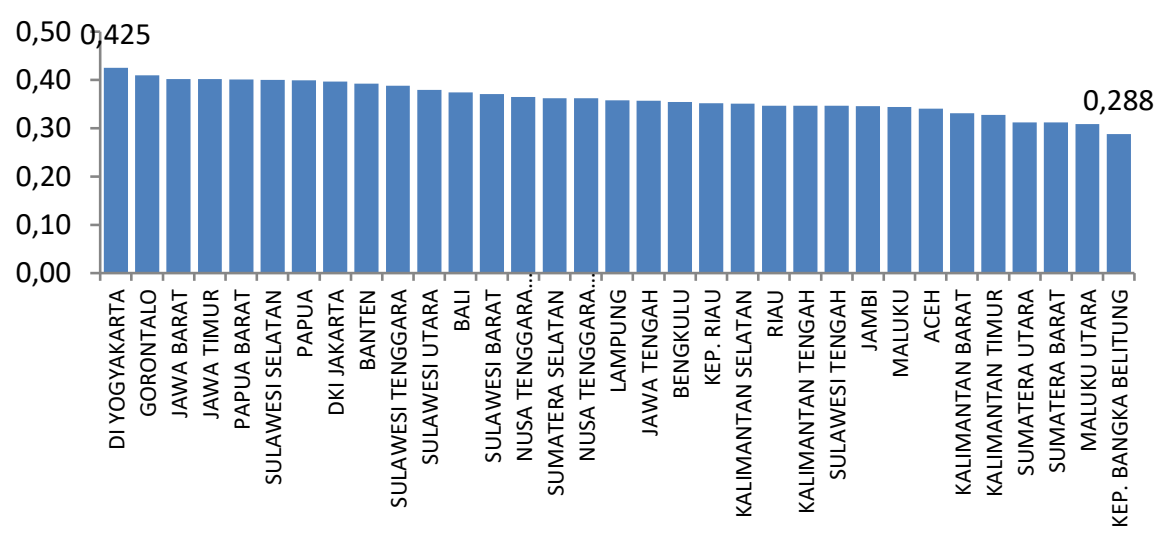

Graph 2. The Gini Ratio of each Province in Indonesia in 2016.

Source: BPS-Statistics Indonesia

The level of inequality of income distribution between provinces in Indonesia is not the same. In Indonesia, the province with the lowest inequality in 2016 was the Province of Bangka Belitung Islands with the Gini Ratio of 0.288 (Graph 2). This result showed that Bangka Belitung Islands had a better distribution of income compared to the other 32 provinces. Whereas, the provinces with the highest inequality were DI Yogyakarta and Gorontalo with 0.425 and 0.4 , respectively. Income inequality in DIY Province tended to be high because several districts/cities had higher per capita income than others. Among them, Sleman and Yogyakarta contributed to more than 50\% of DIY's economic income, while the other three districts only had small contributions. Another reason comes from land expansion and the construction of malls and hotels in urban areas. 


\section{Economic Growth in Indonesia}

Economic growth can be used as a benchmark for the success of a country's economic development. The growth of Gross Domestic Regional Products (GDRP) can illustrate the economic performance. Increasing the volume of economic output is calculated through the GRDP at Constant Market Prices as a measure of economic growth in a given region.

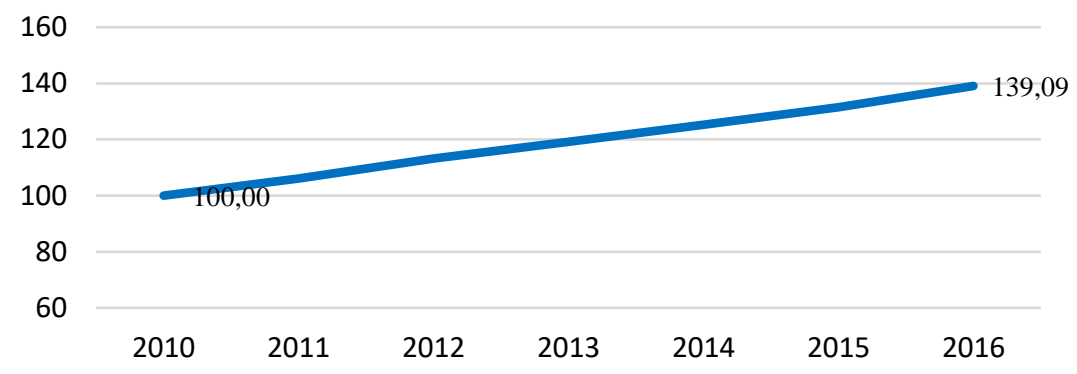

Graph 3. Relative Change Index of the Average GDRP in Indonesia, Years 2010-2016 (2010=100) Source: BPS-Statistics Indonesia (an analysis result)

The Graph above (Graph 3) shows the annual increase in GDRP growth, indicating that economic growth is getting better in Indonesia.

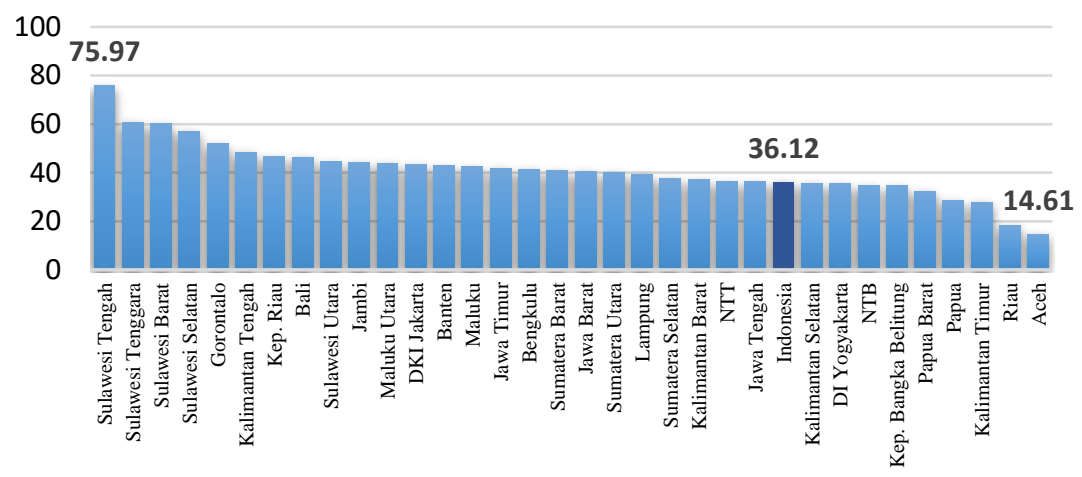

Graph 4. Economic Growth by Province in 2016

Source: BPS-Statistics Indonesia (an analysis result)

Good economic growth in Indonesia does not mean each province has the same economic growth. The graph above shows a very large gap between the provinces with the highest and lowest economic growths. The provinces with the highest economic growths were Central Sulawesi, West Sulawesi and Gorontalo with $75.97 \%$, 60.61\%, and $60.32 \%$, respectively. Meanwhile, the lowest economic growth was observed in Riau Province with 14.61 from 2010 to 2016 (Graph 4).

\section{Infrastructure and economic growth}

The concerned infrastructures include road construction (describing the condition of the road infrastructure as a facilitator in mobilizing goods and services between regions), the percentage of households with access to electricity (illustrating the condition of electrical distribution infrastructure), and the percentage of households with access to sanitation facilities (describing the condition of clean water distribution infrastructure). The 
infrastructure development in a province, especially in rural areas, is expected to encourage economic equality.

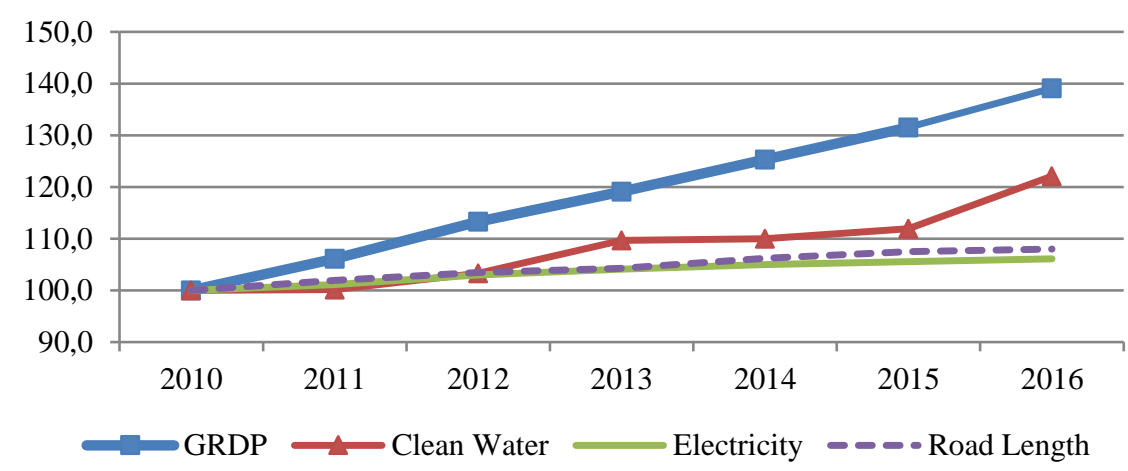

Graph 5. Relative change indexes in averages road length, water distribution, and electricity distribution and GRDP in Indonesia in 2010-2016 (2010=100)

Source: BPS-Statistics Indonesia (an analysis result)

It can be observed that infrastructure has a positive correlation with economic growth. This condition can be seen in Graph 5, where the increase in road length, the percentage of households with access to electricity and proper sanitation is always followed by an increase in economic growth (yearly). This result is evidenced through the increases in road length by $7.99 \%$, the percentage of households with access to electricity by $6.1 \%$, and the percentage of households with adequate sanitation access by $22.1 \%$.

\section{Investment and income inequality}

The investment interest of foreign investors can be seen from foreign direct investment (FDI). A large number of FDI entering Indonesia can also increase employment. FDI will push output and additional workforce to compensate for the incoming FDI. This result will encourage the absorption of the workforce so that economic performance can increase, declining inequality. Graph 6 shows the FDI entering Indonesia and inequality.

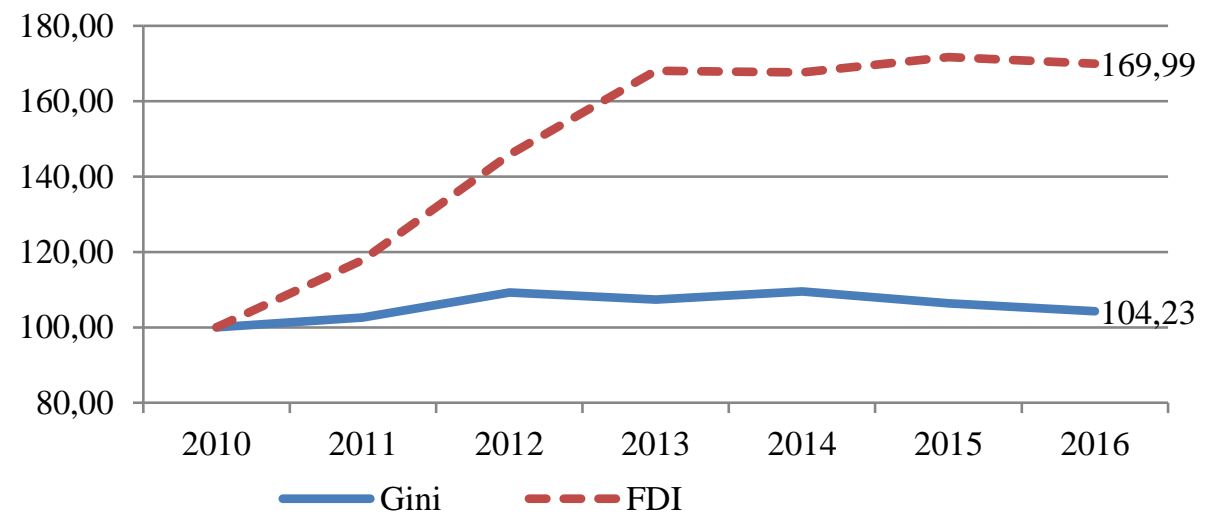

Graph 6. Relative change indexes in income and investment inequality in Indonesia years $2010-2016(2010=100)$ Source: BPS-Statistics Indonesia (an analysis result) 
The Indonesian FDI in 2010-2016 tended to increase. In 2010, the FDI entering Indonesia reached 18.22 billion USD. This figure increased until 2016, where the FDI entering Indonesia reached 30.98 billion USD (Graph 6).
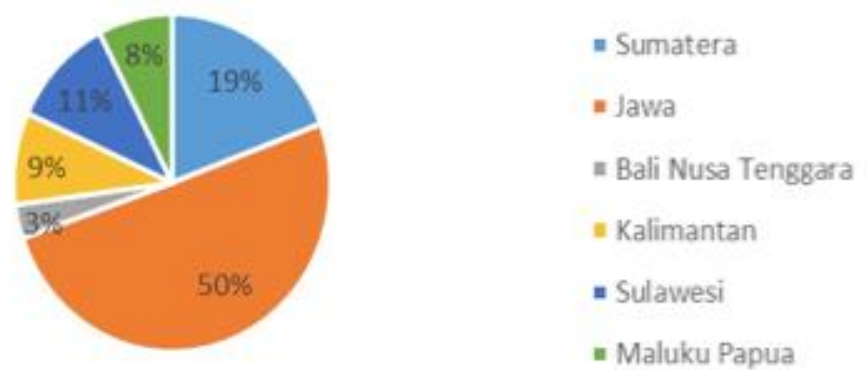

Figure 1. Percentage of FDI realization allocation in Indonesia in 2016 Source: BPS-Statistics Indonesia (an analysis result)

However, FDI entering Indonesia is centered on potential areas. So, it does not increase equality but inequality. It can be seen from the allocation of FDI on the graph, where up to $50 \%$ of the FDI is allocated in Java provinces (Figure 1).

\section{Workforce participation and inequality}

The number of workforces describes the condition of the available human resources ready to conduct economic work. The increasing number of the workforce shows that more people are available to produce goods and services. The correlation between the number of workforces and income inequality in Indonesia tends to be positive.

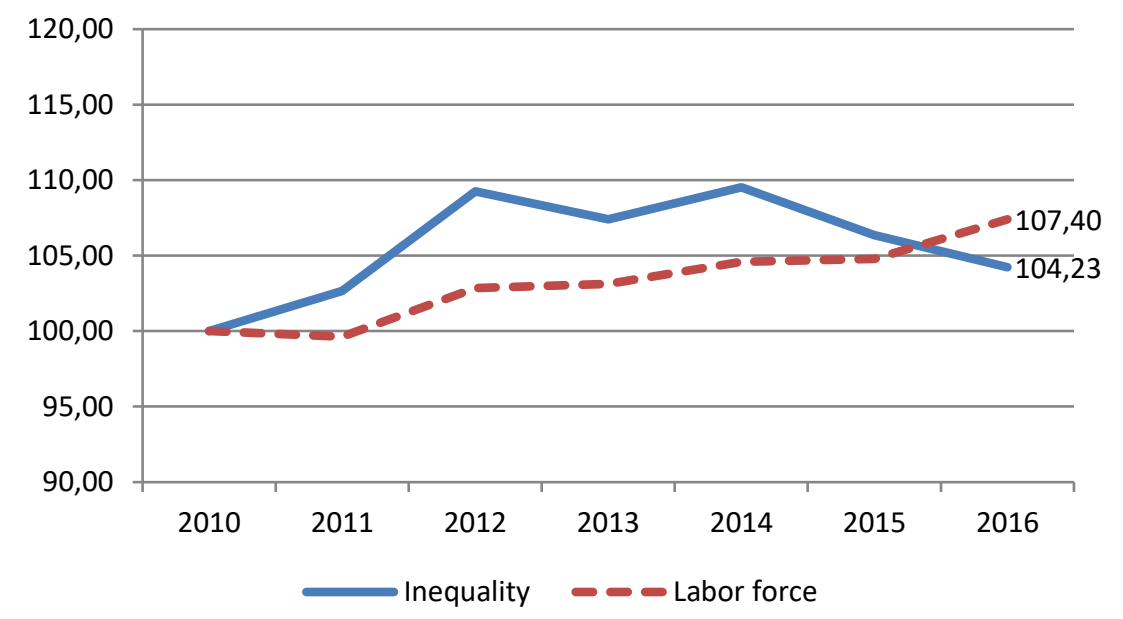

Graph 7. Relative change indexes in income inequality and the number of the labor force in Indonesia in 2010-2016 $(2010=100)$

Source: BPS-Statistics Indonesia (an analysis result)

The average number of the workforce from 2010 to 2016 has increased by $7 \%$ (Graph 7). This increase means that the amount of human resources available to support the economy continues to increase yearly. However, this is not accompanied by a decrease in inequality due to the uneven availability of the workforce, piled up in West Java, Central Java, and East Java. 


\section{Poverty and inequality}

The percentage of the poor shows a detailed comparison between the poor population and other populations in an area. A high percentage of poor in an area means more residents have income below the poverty line in the area, leading to unequal income.

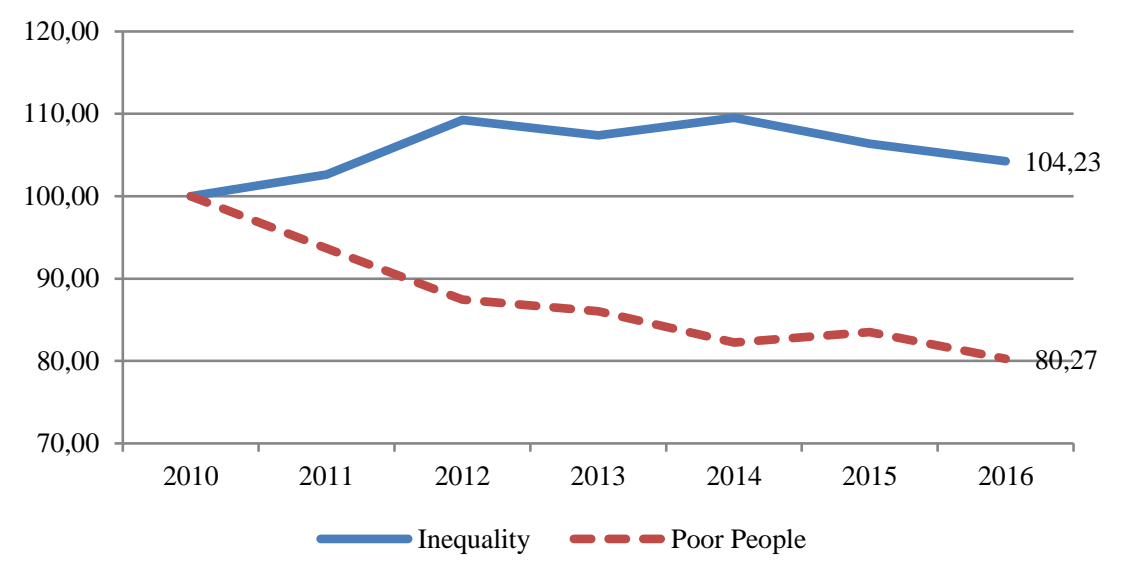

Graph 8. Relative change indexes in income inequality and the percentage of poor people in Indonesia in 2010-2016 $(2010=100)$

Source: BPS-Statistics Indonesia (an analysis result)

In Indonesia, the percentage of the poor population decreased by an average of $19.8 \%$ from 2010 to 2016 (Graph 8). This result indicated that economic growth in Indonesia is good. However, the decline in the percentage of the poor population was not in line with the average increase in inequality by $5 \%$ since 2010 .

\section{Economic growth and inequality}

Economic growth and income inequality go hand in hand; changes in income inequality will be followed by changes in economic growth.

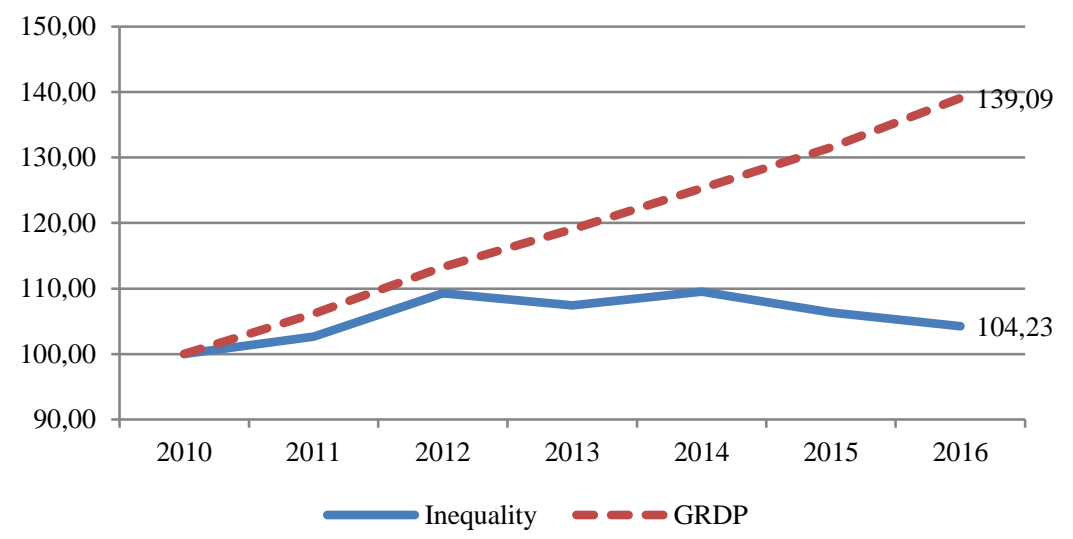

Graph 9. Relative change indexes in income imbalance and economic growth in Indonesia in 2010-2016 $(2010=100)$.

Source: BPS-Statistics Indonesia (an analysis result)

The above Graph (Graph 9) showed that the economic growth described in GDRP always increases yearly. However, inequality, in this case, the Gini Ratio fluctuates. In 2010- 
2013, there was an increase that followed the economic growth and tended to decline in 20132016.

\section{Analysis of the relationship between economic growth and inequality and the influencing factors}

\section{Economic growth equations}

Table 1 revealed that the economic growth equation was significant in the $\mathrm{F}$ test, with a probability of 0,000 . This result meant that with a $95 \%$ confidence level, all explanatory variables of economic growth equations had significant effects on economic growth. Also, the value of R2 can be identified as 0.9891 , meaning that the explanatory variables of $98.91 \%$ can explain the variation in the value of economic growth. Meanwhile, other variables outside the model can explain the $1.09 \%$. The economic growth equation is as follows:

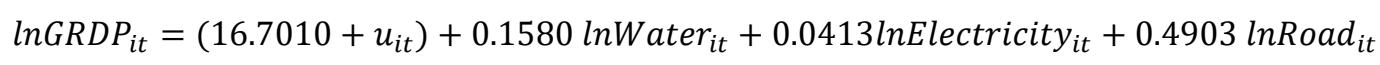

Table 1. Summary of economic growth equations

\begin{tabular}{|c|c|c|c|c|}
\hline Endogenous Variables & $\begin{array}{c}\text { Exogenous } \\
\text { Variables }\end{array}$ & Coefficient & t-Statistic & p-values \\
\hline (1) & $(2)$ & (3) & (4) & (5) \\
\hline \multirow{4}{*}{ Per capita GRDP } & & 16.7010 & 1.5950 & $0.0000^{*}$ \\
\hline & Water & 0.1580 & 2.9055 & $0.0002^{*}$ \\
\hline & Electricity & 0.0413 & 13.6063 & $0.0000^{*}$ \\
\hline & Road & 0.4903 & 2.1341 & $0.0000^{*}$ \\
\hline$R$-squared & 0.9908 & \multicolumn{2}{|c|}{ Adj R-squared } & 0.9891 \\
\hline$F$-Statistic & 601.63 & \multicolumn{2}{|c|}{ Prob (F-Statistic) } & $0.0000^{*}$ \\
\hline
\end{tabular}

Source: author's analysis

The estimation results revealed that the variables of water and electricity distribution and road length had significant positive effects on GRDP growth. The coefficient value for the water distribution variable was 0.1580 , meaning every $1 \%$ increase in households with proper sanitation access can increase economic growth by $0.1580 \%$, assuming ceteris paribus. For the electricity distribution variable, the coefficient value was 0.0413 , meaning that economic growth will increase by $0.1580 \%$ for every $1 \%$ increase in electricity distribution. The coefficient value for the road length variable was 0.4903 , meaning that every $1 \%$ increase of road length access can increase economic growth by $0.4903 \%$.

\section{The equation of income inequality}

The equation of income inequality is as follows:

$$
\begin{aligned}
\text { Gini }_{i t}=(1.9503 & +\mathrm{u} 2 \mathrm{i})-0,0992 \ln \widehat{G R D} P_{i t} \\
& -6,3310^{-6} \operatorname{lnFDI}_{i t} 4,6710^{-8} 8 \ln \text { Workforce }_{i t^{-}} 0,0033 \ln _{\text {noor }} \text { or }_{i t}
\end{aligned}
$$


Table 2. Summary of similarities in income inequality

\begin{tabular}{clccc}
\hline $\begin{array}{c}\text { Endogenous } \\
\text { Variables }\end{array}$ & \multicolumn{1}{c}{ Exogenous Variables } & Coefficient & t-Statistic & p-values \\
\hline \multicolumn{1}{c}{$(\mathbf{1})$} & \multicolumn{1}{c}{$(\mathbf{2})$} & $\mathbf{( 3 )}$ & $\mathbf{( 4 )}$ & $\mathbf{( 5 )}$ \\
\hline Gini Ratio & $\mathrm{C}$ & 1.9503 & 2.9393 & $0.0037^{*}$ \\
& Per capita GRDP & -0.0992 & -2.5512 & $0.0115^{*}$ \\
& FDI & -0.0063 & -2.0631 & $0.0404^{*}$ \\
& Workforce & 0.0467 & 5.6852 & $0.0000^{*}$ \\
& Poor & -0.0033 & -2.5811 & $0.0106^{*}$ \\
\hline$R$-squared & 0.8348 & Adj $R$-squared & 0.8041 \\
\hline F-statistic & 27.2444 & Prob (F-statistic) & $0.0000^{*}$ \\
\hline
\end{tabular}

Source: author's analysis

Table 2 shows that the equation of income inequality was significant in the $\mathrm{F}$ test with a probability of 0.000 . This result means that a $95 \%$ confidence level, all explanatory variables of economic growth equations had significant effects on economic growth. Besides, the value of the $\mathrm{R}^{2}$ was identified as 0.8041 , meaning that the variation in the value of income inequality can be explained by $80.41 \%$ explanatory variables, while other variables outside the model can explain the $19.59 \%$.

The estimation results revealed that there was a correlation between the Gini Ratio and GRDP growth in Indonesia, where the growth of the provincial GRDP negatively affected the Gini Ratio. The GRDP growth coefficient value of -0.0992 , assuming other variables remain the same or ceteris paribus, showed that for every 1\% increase in GRDP growth, the income inequality would be reduced by 0.0009 points. This result is in line with Kuznet's theory stating that inequality and economic growth will be negatively correlated in the long run. According to Kuznets (in Kuncoro, 2006), economic growth in developing countries initially caused a high level of inequality in income distribution. However, if the developing countries are more advanced, the problem of poverty and inequality in income distribution will decrease (an inverse U shaped pattern).

Other independent variables that significantly influence the Gini ratio are the number of workforce and FDI, while the percentage of the poor population has no significant effect on it. The workforce significantly and positively influences the Gini coefficient Ratio $(0,0467)$, meaning that for every workforce, the Gini Ratio will increase by 0,0467 points, assuming ceteris paribus. This condition happened because of the uneven allocation of labor, as labor growth was concentrated in only a few provinces, leading to increased inequality.

\section{Conclusion}

The findings showed that there was a direct influence of the provision of public infrastructure on economic growth. The development of basic service infrastructure (access to clean water, access to electricity, and roads) affects increasing economic growth. Of the three basic infrastructures, the road had a greater influence than other infrastructures in increasing economic growth. The construction of highways allows increased connectivity between regions, driving economic activity, which in turn has the potential to increase economic growth. 
The results of the analysis also showed that economic growth, foreign direct investment, and poverty levels affected the reduction in income inequality. The decrease in poverty level affects reducing income inequality. To that end, the strategy of improving economic growth needs to involve the poor. This scenario will provide opportunities for the poor to participate in the development. The involvement of the poor in development is expected to reduce the gap between the poor and the rich, to reduce income inequality.

What's interesting is that the number of the workforce increases income inequality. This result shows that job creation was not in pace with the growth of the workforce looking for jobs to increase income. However, it does not make sense to reduce the workforce, but what is more realistic is the acceleration of employment in each province.

The findings further indicate that the availability of infrastructure in the form of proper sanitation, electricity distribution, and road density, positively and significantly affects economic growth. Thus, the availability of basic infrastructure indirectly affects the decrease in income savings between regions in Indonesia.

Based on the findings above, the Indonesian government and related agencies are advised to continue to develop basic infrastructure and transportation to improve economic performance to reduce income inequality sustainably.

\section{References}

Arsyad, L. (1999). Ekonomi Pembangunan (Development Economic), Yogyakarta: STIE YKPN.

Badan Pusat Statistik (Central Statistic Bureau). Berbagai Edisi (Many Editions). Statistik Indonesia. Jakarta: Central Statistic Bureau

Baltagi, B. H. (2005). Econometric analysis of panel data. Wiley \& Sons Ltd. Chicester.

Berndt, E. R., \& Hansson, B. (1991). Measuring the contribution of public infrastructure capital in Sweden (No. w3842). National Bureau of Economic Research.

Byoungki, K. I. M. (2006). Infrastructure development for economic development in developing countries: Lessons from korea and japan. Kobe: Kobe University.

Chingoiro, S., \& Mbulawa, S. (2016). Economic growth and infrastructure expenditure in Kenya: A Granger-Causality approach. Int'l J. Soc. Sci. Stud., 4, 1.

Chong, A., \& Calderon, C. (2001). Volume and Quality of Infrastructure and the distribution of Income: An Empirical Investigation. Working Paper, Inter-AmericanDevelopment Bank, Research Department, No. 450

Fay, M. (2001). Financing the Future: Infrastructure Needs in Latin America, 2000-2005. World Bank, Latin America, and the Caribbean Region, Finance, Private Sector, and Infrastructure Sector Unit.

Fay, M., \& Yepes, T. (2003). Investing in Infrastructure: What is Needed from 2000 to 2010 ?. The World Bank.

Gujarati, D. N. (2004). Basic Econometrics. New York: McGraw-Hill

Hidayat, M. H. (2014). Analisis Pengaruh Pertumbuhan Ekonomi, Investasi, dan IPM Terhadap Ketimpangan Pendapatan Antar Daerah di Provinsi Jawa Tengah Tahun 2005-2012 (Analysis of the Effects of Economic Growth, Investment, and HDI Against Inequality between Regional Income in Central Java Province 2005-2012. [Skripsi]. Semarang: Universitas Diponegoro.

Hajiji, H. (2010). Keterkaitan AntaraPertumbuhan Ekonomi Ketimpangan pendapatan, dan Pengentasan kemiskinan di Provinsi Riau 2002-2018. Sekolah Pascasarjana Institut Pertanian Bogor

Hirschman, A. (1958). The Strategy of Economic Development. Yale Univ. Press, New Haven and London. 
Kodongo, O., \& Ojah, K. (2016). Does infrastructure really explain economic growth in SubSaharan Africa? Review of Development Finance, 6 (2), 105-125.

Kuncoro, M. (2004). Otonomi \& Pembangunan Daerah: Reformasi, Perencanaan, Strategi, dan Peluang (Regional Autonomy \& Development: Reform, Planning, Strategy, and Opportunity). Jakarta: Erlangga.

Mankiw, N. G. (2009). Macroeconomics 7th Edition. New York: Worth Publishers.

Mbulawa, S. (2017). The impact of economic infrastructure on long term economic growth in Botswana.

Morrison, C. J., \& Schwartz, A. E. (1992). State infrastructure and productive performance (No. w3981). National Bureau of Economic Research.

Tambunan, Tulus. (2003). Perekonomian Indonesia :Beberapa Masalah Penting (Indonesian Economic: Some Important Problem). Jakarta: Ghalia Indonesia.

Owolabi-Merus, O. (2015). Infrastructure development and economic growth nexus in Nigeria. International Journal of Academic Research in Business and Social Sciences, 5(1), 376.

Todaro, M.P. \& Smith, S.C. (2012). Economic Development 11th Edition. Boston: Pearson Education, Inc.

Yeniwati \& Riani, N. Z. (2012). Analisis Faktor yang Mempengaruhi Ketimpangan Pembangunan di Pulau Sumatera (An Analysis of Factors Affecting Development Inequality on Sumatra Island). Laporan Dosen Pemula. Universitas Negeri Padang. 